DOI: 10.46340/eppd.2020.7.2.42

Diana Nazarenko

ORCID ID: https://orcid.org/0000-0003-2235-6588

National Academy of Public Administration under the President of Ukraine

\title{
LOCAL RULEMAKING AS A TOOL FOR THE FORMATION OF THE ADVOCACY SYSTEM
}

This article reviews the meaningful problem of the formation of the advocacy system through local rulemaking and actualization of the mechanisms of direct democracy in the course of citizens' access to direct participation in local government.

While there is a legislative fixation of citizens' rights to participate in government of local affairs, we've established a low efficiency of the advocacy due to the imperfection of the mechanisms of the territorial community involvement. This is manifested in the incompleteness of the local legal framework, which can be modified by the development and signing of social contracts at the level of territorial communities that would supplement the existing local legal framework.

The central mechanisms of mass social mobilization should be represented by the simplicity of formal requirements for advocacy and a positive belief in the possible changes in the social life of the territorial community, which is based on the implementation of successful contractual practices. Keywords: advocacy, community, local self-government, social contract.

Relevance of research. Statement of the problem. During the reform of local self-government, the relative unification of the structure and vectors of territorial communities' activity negatively impacted the development of the local democracy forms (which number and forms do not expand) and the presence of certain paternalistic sentiments in society, which affected the negative implementation of decentralization processes and insufficient indicators of formation of amalgamated territorial communities (hereinafter referred to as ATC). One of the possible ways to overcome this problem could be the active use of the advocacy system, which is interpreted not only as representation and protection of the interests of vulnerable elements of the socio-economic taxon but also as the promotion of values.

Current state of the problem's research and identification of its unexplored parts. The problematic field of advocacy is reflected in the writings of foreign researchers: $:^{1,2,3,4,5,6,7}$, and domestic scientists ${ }^{8,9,10,11}$.

\footnotetext{
${ }^{1}$ Planet Advocacy Magazine. Action For Advocacy. $<$ http://www.actionforadvocacy.org.uk/articleServlet_action=list\&articletype=22>.

${ }^{2}$ Manthorpe, J., Rapaport, J., Hussein, S., Moriarty, J., Collins, J. (2006). Advocacy and People with Disabilities:

Localthe power of the sphere of its activity, degree and efficiency. London: Kings College London.

${ }^{3}$ Obar, J.A., Zube, P., Lampe, C. (2012). Advocacy 2.0: An analysis of how advocacy groups in the United States perceive and use social media as tools for facilitating civic engagement and collective action. Journal of Information Policy, 2, 1-25. doi:10.2139/ssrn.1956352. SSRN 1956352.

${ }^{4}$ Keck, Margaret E., Sikkink, K. (1998). Activists beyond Borders Advocacy Networks in International Politics. Cornell University Press, 16.

${ }^{5}$ A review of evidence of the bar and its practice for people with limited learning opportunities and high need of support, adults Paper Service 24. SCIE. <http://www.scie.org.uk/>.

${ }^{6}$ Kremers, D. (2014). Transnational Migrant Advocacy From Japan: Tipping the Scales in the Policy-making Process. Pacific Affairs, 87 (4), 733. doi:10.5509/2014874715.

${ }^{7}$ Beresford, P., Croft, S. (2004). Users of the service and Practitioners are reunited: a key component of social work reform. British Journal of Social Work, 34 (1), 53-68.

${ }^{8}$ Ефективні антикорупційні інструменти - громадський моніторинг та кампанії адвокасі. Адвокасі кампанії як інструмент системних перетворень суспільства у протидії проявам корупції.

$<$ https://advocacyresourse.files.wordpress.com/2016/03/d0b5d184d0b5d0bad182d0b8d0b2d0bdd0b8d0b9-

d196d0bdd181d182d180d183d0bcd0b5d0bdd182.pdf $>$.

${ }^{9}$ Кіященко, Г. Адвокасі. Практичний посібник. $<$ https://issuu.com/gurtrc/docs/advocacy>.

${ }^{10}$ Патенок, Н.Я. (уклад.) (2014). Адвокація в бібліотеці: методико-інформаційні рекомендації. Київ.

${ }^{11}$ Кобець, Р., Панцир, С. (ред.) (2008). Публічне лобіювання: навчальний посібник. Київ: Фонд “Європа ХXI”.
} 
Local rulemaking is analyzed in the works of modern domestic scholars, in particular ${ }^{1,2,3,4,5}$. Simultaneously, the issues of local rulemaking as a tool for forming the advocacy system at the local level haven't yet been the subject of a separate study, which entails the preparation of this article.

The purpose of the article is to substantiate the principles of improving local rulemaking to form an advocacy system at a local level.

Presentation of the basic material. Today, the coefficient of social and political effectiveness of advocacy is not high enough, due to the lack or imperfect mechanisms (including legal) for citizens to directly participate in government. Analyzing the modern legal framework, we can conclude that some aspects of the regulation of advocacy can be found in the current Constitution of Ukraine and some laws. For example, Article 3 of the Constitution of Ukraine establishes that "A person, his ther life and health, honor and dignity, integrity and security are recognized in Ukraine as the highest social value. Human rights and freedoms and their guarantees determine the content and orientation of the state. The state is responsible for its activities before the person. Promoting and securing human rights and freedoms is a major responsibility of the state" ${ }^{6}$. An important place in the structure of legal support of advocacy belongs to the institute of public appeals. Thus, the Law of Ukraine "On Citizens' Appeals" states, in particular, the following: "The law provides citizens of Ukraine with opportunities to participate in the state and local government, to influence the improvement of the work of state authorities and local self-government, enterprises, institutions, organizations regardless of their property forms, to assert their rights and legitimate interests and restore them in the event of a violation" ${ }^{7}$. Analyzing the legal framework of advocacy, we should mention another tool aimed at representation of citizens' interests in public authorities, namely through forms of direct democracy. Recently, they have been receiving a lot of attention, so these issues were also highlighted in our study on the institutionalization of the local advocacy in Ukraine and methodological approaches to the analysis.

Summarizing the aforesaid, it should be noted that the current political and legal reality demonstrates the growing need to improve legislation on the regulation of representation of citizens' interests and their associations in local public authorities. The formation of a full-fledged civil society is possible only in the presence of effective mechanisms for the development of advocacy, which we consider as a form of civil lobbying. Despite the fact that the rights of citizens and their associations to represent their demands and expertly participate in the work of the system of local self-government bodies are legally enshrined, the possibilities of their realization are still insufficiently implemented due to the incompleteness of the local regulatory and legal field. Thus, according to expert estimates, less than $18 \%$ of modern territorial communities have a Charter.

As stated in the materials of state policy in the field of local self-government, the decentralization reform should be completed by autumn $2020^{8}$. In our opinion, the new construction of the local selfgovernment system (hereinafter - LSGS) should appear in the reform process. As known, the concept of construction (Latin constructio) means "building, relative arrangement of parts ... links" ${ }^{9}$. Constructions obtain legal significance when they are included in the content of the law when certain structural models are

\footnotetext{
${ }^{1}$ Бабінова, О.О. (2004). Взаємодія органів державного управління та місцевого самоврядування з громадськістю як предмет теоретичного аналізу. Вісник НАДУ, 3, 345-353.

${ }^{2}$ Кальниш, Ю.Г. (2008). Пряма демократія в Україні: історичні традиції та перспективи розвитку. Стратегічні пріоритети, 4, 5-15.

${ }^{3}$ Вакуленко, В.М., Берданова, О.В., Гринчук, Н.М., Колтун, В.С., Куйбіда, В.С. (2017). Управління розвитком об'єднаних територіальних громад на засадах громадської участі. Практичний посібник. Київ.

${ }^{4}$ Koltun, V. (2018). Complexiti as the immunental properties of local-self-governance phenomenon. Relevant issues of development and modernization of the modern science: the experience of countries of eastern Europe and prospects of Ukraine. Riga, 160-182. DOI: http://dx.doi.org/10.30525/978-9934-571-26-8_9

5 Радченко, О.В. (2011). Форми безпосередньої демократії територіальної громади. Держава та регіони. Серія: Державне управління, 2, 141-145.

${ }^{6}$ Конституиія Украйни 1996 (Верховна Рада України). Офіиійний веб-сайт Верховної Ради Украӥни.

$<$ https://zakon.rada.gov.ua/laws/show/254\%D0\%BA/96-\%D0\%B2\%D1\%80>.

7 Закон про звернення громадян 1996 (Верховна Рада України). Офіиійний веб-сайт Верховної Ради Украӥни.

$<$ https://zakon.rada.gov.ua/laws/show/393/96-\%D0\%B2\%D1\%80>.

${ }^{8}$ Місцеві вибори в Україні пройдуть восени 2020 року, - голова Верховної Ради.

$<$ https://decentralization.gov.ua/news/11876>.

${ }^{9}$ Словник української мови: в 11 томах (1973). Том 4. Київ: Наук. думка, 266.
} 
constructed from legal norms, that, in one way or another, allow explaining the legal reality, specific legal phenomena, to achieve established goals and necessary legal results ${ }^{1}$. However, legal determinism is not a guarantee of public activity in the implementation of political innovations. Thus, in our opinion, it is the civil activity of the population that is the most important factor for the effective implementation of a promising model of local self-government. The moods and expectations of the population regarding the possibility of a new political situation should be based on the relevant local legal framework and the accumulated experience of solving identical situations. The central mechanisms of mass social mobilization should be represented by the simplicity of formal requirements for advocacy and a positive belief in the possible changes in the social life of the territorial community, which is based on implemented successful practices. Besides, civil experimentation in society makes a fundamental transition in the very nature of local democracy generally possible, namely, the development and signing of social contracts at the level of territorial communities that would supplement the existing local legal framework.

The emergence of the term "social contract" is closely linked to the development of the Enlightenment philosophy. For the most part, it was considered in the context of the development of civil society concept as a certain type of state, which arises from the social contract concluded for the protection of natural rights and freedoms of $\operatorname{man}^{2}$. The social contract was covered in the writings of such prominent philosophers like John Locke and Thomas Hobbes, Friedrich Hegel and Jean-Jacques Rousseau. Rousseau, for example, believed that a social contract is an association formed to protect the personality, property and civil liberty of individuals, each of whom submits to a common will ${ }^{3}$. He constantly emphasized the collectivism that emanates from the equality of all members of society in relation to the supreme power, which, in turn, does not favor any of them ${ }^{4}$. A social contract once and for all gives citizens equal rights and obligations that they cannot escape. The social contract establishes a formalized equality among citizens, by virtue of which they must obey equal conditions and enjoy equal rights ${ }^{5}$. Today, only the basis is left from the primary concept of a social contract: the recognition that the achievement of a social order suitable for the majority requires the development of effective mechanisms for reconciling the interests of public institutions. The basis of the new social contract is the idea of a permanent negotiation process between civil society and local public authorities ${ }^{6}$.

A social contract is a written agreement, a way to consolidate good practice and formalize interaction between public authorities and public organizations to ensure equal cooperation between the parties on the way to solving existing problems and promoting community development ${ }^{7}$. Nowadays, a social contract ("compact") is understood as the form of an agreement on the principles and mechanisms of cooperation between public authorities and non-governmental organizations. Different countries that practice this form of sector-to-sector cooperation call this agreement differently. In England and Wales, for example, this is called a memorandum on the relationship between government and the voluntary, public sector. In Northern Ireland, it is called a jointly prepared and agreed statement of common principles and shared values that guide the development of relations between the government and voluntary, public sector. In Estonia, the "compact" is adopted by the Parliament as the "Concept of Civil Society Development". However, despite the diversity of definitions and interpretations, the essence of signing a social contract is one - building partnership and effective interaction between the government and public institutions for the benefit of the community ${ }^{8}$.

\footnotetext{
${ }^{1}$ Костюков, А.Н. (2003). Муниичиальное право как отрасль российского права. Москва, 131.

2 Підлуська, І., Голюк, О. (2006). Суспільний договір: від філософії давнини до потреб сучасності. Наша громада, 2 (9), 5-8.

${ }^{3}$ Руссо, Жан-Жак, Хома, О. (пер.) (2001). Про суспільну угоду, або Принциии політичного права. Київ: Port-Royal.

${ }^{4}$ Руссо, Жан-Жак, Хома, О. (пер.) (2001). Про суспільну угоду, або Принциипи політичного права. Київ: Port-Royal.

${ }^{5}$ Підлуська, І., Голюк, О. (2006). Суспільний договір: від філософії давнини до потреб сучасності. Нама громада, 2 (9), 5-8.

${ }^{6}$ Підлуська, І., Голюк, О. (2006). Суспільний договір: від філософії давнини до потреб сучасності. Нама громада, 2 (9), 5-8.

${ }^{7}$ Куйбіда, С., Петроє, О.М., Дегтярьова, І.О. (ред.) (2018). Теорія та практика публічного управління та адміністрування у XXI сторіччі: матеріали I Всеукраїнської науково-практичної конференції за міжнародною участю здобувачів вищої освіти тамолодих вчених (Київ, 30 листопада 2018 р.). Київ: НАДУ.

${ }^{8}$ Сурмін, Ю.П., Михненко, А.М., Крушельницька, Т.П. та ін. (2011). Взаємодія органів державної влади та громадянського суспільства: навчальний посібник. Київ: НАДУ.
} 
We should mention that the territorial communities of Ukraine already have a practice of signing similar social contracts. Experience of Kherson $\mathrm{ATC}^{1}$ and Sambir ATC ${ }^{2}$ is of great interest.

One of the most important factors in the effectiveness of a promising model of local self-government, that can be constructed due to the dissemination of advocacy tools, should be a regular review of commitments made by LSG bodies and the population according to a social contract. "Social contract exists in the mass consciousness as a regulatory idea, as a necessary element in the ideology of reform, as the most important element of Ukraine's transition to a modern civilized, legal and democratic society. However, in order to make the idea of a social contract a reality, it is necessary to ensure the representation and protection of certain groups of society in their dialogue with each other and with the public authorities" ${ }^{3}$.

Increasing public participation in local development processes (in particular, by representing and protecting the interests of vulnerable elements of the socio-economic taxon) will inevitably affect the transformation of LSG structure. This may continue the transition of LSG, which began with Ukraine's independence and constitutional guarantees of local self-government, from the status of "primary elements of the system of administrative state mechanism" to the status of "means of realization of interests and will of self-governing communities". Obviously, the continuation of these changes requires a revision of the whole concept of the system of organization and management of local development.

First of all, when constructing a new organizational and managerial concept, we should remember that the potential of the conscious community in ATC is gradually increasing, which can ensure the realization of the constitutional status of ATC as a subject and bearer of the right to local self-government (Art. 140 of the Constitution of Ukraine). This implies the formation of prerequisites for the newest forms of civic activity, first of all, advocacy, which we interpret not only as representation and protection of interests but also as a tool for promoting values. These principles should be reflected at the organizational and legal level in the form of innovative and/or updated local regulations (ATC Charters, social contracts, etc.).

One of the most important determinants of a promising model of local self-government should be the transparency of activities of LSG bodies and officials. Thus, reducing the level of corruption will help to find the essential resources needed to solve the social problems of the territorial society. "If the driving force of civil society is the competitive relationship between individuals and their associations, in local selfgovernment it is the activity of citizens aimed at achieving the common local interest, ensuring social coherence, and a decent standard of living" ${ }^{4}$. In addition to the steps implemented at the national level ${ }^{5}$, the necessary measures should be implemented at the local level as well.

Foreign experience demonstrates to us that the possibility of carrying out the entrepreneurial activity with initial reliance on the resources of the territorial community is very important for the development of economic activity of the population. For example, in Italy in the early 1980s, the so-called Emilian model (in honor of the Italian region of Emilia Romagna) became widespread in the interaction between LSG and small businesses. Local authorities, in particular, provided land at low prices, gave preferential loans for development, provided guarantees needed to obtain loans from banks, developed information systems for entrepreneurs, etc. At the same time, the focus was on small businesses with no more than ten employees ${ }^{6}$. It is well-known that the government of modern Ukraine pays a lot of attention to the development of small business, and the corresponding initiative of local self-government can find support at the highest level.

The reform aimed at strengthening the democratic foundations of the local self-government means real steps to reduce democratic deficits. American political scientists Mark Warren and Hilary Pearse in their

\footnotetext{
${ }^{1}$ В Херсоні підписано перший суспільний договір в сфері місцевого самоврядування. Херсон.Громада.Ініціатива. <https://www.hgi.org.ua/?ch=info_vyb_psd>.

${ }^{2}$ Агенство регіонального розвитку Самбірщини. Офіиійний сайт Самбірської районної ради. $<$ https://sambirrada.gov.ua/agenstvo-regionalnogo-rozvitku-sambirshhini/>.

3 Паршина, Е.Н. (2009). Общественный договор как модель взаимодействия институтов и организаций гражданского общества с органами власти. Политическая наука на Юге России: итоги двадиатилетнего развития: сборник материалов международной научно-практич. конф. Ростов на Дону: Изд-во СКАГС, 411-415. ${ }^{4}$ Тимофеев, Н.С. (2005). Местное самоуправление в системе государственных и общественных отношений. История и современность. Москва, 162.

${ }^{5}$ Прийнято за основу проект Закону "Про внесення змін до Податкового кодексу України щодо функціонування електронного кабінету та спрощення роботи фізичних осіб-підприємців". Офіųійний веб-сайт Верховної Ради України. <https://rada.gov.ua/news/Novyny/186699.html>.

${ }^{6}$ Местные органы власти: Предпринимательство в Италии (1994). Москва.
} 
monograph, describe democratic deficit "as violations of the boundaries between the citizen's possibilities and requirements, and the capabilities of political institutions that combine the citizen's requirements and integrate them into the relevant legal rules of effective government"1.

In the future, modern democracy must be updated with different forms of advocacy. The proposed model of local self-government should increase public confidence in LSG officials and employees and strengthen the economic base of local communities. The balance of rational and irrational actions of the political elite of LSG should be changed in favor of the priority provision of interests of the population and the innovative development of territories. The advocacy system should become the main tool, which, in turn, requires updating the local legal framework to create an organizational and legal basis for its implementation.

At the same time, it would be a mistake to rely solely on a free-flowing mass movement focused on public reform of the LSGS. It should not only be about increasing the population's involvement in solving local problems, but also about enhancing the role of the LSG structures in the implementation of social policy. Undeniably, the institutional base for innovative development of local self-government still needs to be created, and the necessary socio-political resources must be consolidated based on deliberative democracy, which paradigm closely correlates with the principles of advocacy.

Also, what's important is to avoid imitations of the new freedom of thought that will inevitably be cultivated by that part of the ruling local elite not interested in political reform. Creating a mechanism for solving these problems has objective and subjective difficulties, linked both to the peculiarities of the deployment of political processes in modern Ukraine, as well as to the subjective capabilities and willful efforts of the political elite and citizens, and awareness of the need for active involvement in local government reform by the latter.

Conclusions. As a result of the study, we have substantiated the principles of improving local rulemaking for the formation of the advocacy system at the local level, namely: based on the analysis of foreign experience and best domestic practices, we've proved the expediency of using the potential of social contracts at the level of territorial communities; established that one of the most important factors in the effectiveness of a promising model of local self-government, that can be constructed due to the dissemination of advocacy tools, should be a regular review of commitments made by LSG bodies and the population according to a social contract. We've also clarified that one of the most important determinants of a promising model of local self-government should be the transparency of activities of LSG bodies and officials, for which modern democracy must be updated with various forms of advocacy.

\section{References:}

1. Ahenstvo rehionalnoho rozvytku Sambirshchyny (2020). [Sambir Region Regional Development Agency]. Ofitsiinyi sait Sambirskoi raionnoi rady [The official site of the Sambir District Council].

$<$ https://sambirrada.gov.ua/agenstvo-regionalnogo-rozvitku-sambirshhini/>. (2020, March, 15). [in Ukrainian].

2. Babinova, O.O. (2004). Vzaiemodiia orhaniv derzhavnoho upravlinnia ta mistsevoho samovriaduvannia $\mathrm{z}$ hromadskistiu yak predmet teoretychnoho analizu [Interaction of public authorities and local self-government with the public as a subject of theoretical analysis]. Visnyk NADU [NADU Herald], 3, 345-353. [in Ukrainian].

3. V Khersoni pidpysano pershyi suspilnyi dohovir v sferi mistsevoho samovriaduvannia (2020) [In Kherson the first social contract in the field of local self-government was signed]. Kherson.Hromada.Initsiatyva [Kherson. Community. Initiative]. <https://www.hgi.org.ua/?ch=info_vyb_psd>. (2020, March, 15). [in Ukrainian].

4. Vakulenko, V.M., Berdanova, O.V., Hrynchuk, N.M., Koltun, V.S., Kuibida, V.S. (2017). Upravlinnia rozvytkom obiednanykh terytorialnykh hromad na zasadakh hromadskoi uchasti. Praktychnyi posibnyk [Managing the development of integrated territorial communities on a participatory basis. A practical guide]. Kyiv. [in Ukrainian].

5. Efektyvni antykoruptsiini instrumenty - hromadskyi monitorynh ta kampanii advokasi (2016). Advokasi kampanii yak instrument systemnykh peretvoren suspilstva u protydii proiavam koruptsii [Effective anti-corruption tools public monitoring and advocacy campaigns. Advocacy campaigns as a tool for systemic societal transformation in combating corruption].

$<$ https://advocacyresourse.files.wordpress.com/2016/03/d0b5d184d0b5d0bad182d0b8d0b2d0bdd0b8d0b9d196d0bdd181d182d180d183d0bcd0b5d0bdd182.pdf>.(2020, March, 15). [in Ukrainian].

6. Zakon pro zvernennia hromadian, 1996 [Citizens Appeal Act 1996] (Verkhovna Rada Ukrainy) [(Verkhovna Rada of Ukraine)]. Ofitsiinyi veb-sait Verkhovnoi Rady Ukrainy [The official website of the Verkhovna Rada of Ukraine]. <https://zakon.rada.gov.ua/laws/show/393/96-\%D0\%B2\%D1\%80>. (2020, March, 15). [in Ukrainian].

${ }^{1}$ Warren, M.E., Pearse, H. (eds.) (2008). Designing Deliberative Democracy: The British Columbia Citizens' Assembly. New York: Cambridge University Press, 2. 
7. Kalnysh, Yu.H. (2008). Priama demokratiia v Ukraini: istorychni tradytsii ta perspektyvy rozvytku [Direct democracy in Ukraine: historical traditions and development prospects]. Stratehichni priorytety [Strategic priorities], 4, 5-15. [in Ukrainian].

8. Kiiashchenko, H. (2020). Advokasi. Praktychnyi posibnyk [Advocate. A practical guide]. $<\mathrm{https}$ ://issuu.com/gurtrc/docs/advocacy>. (2020, March, 15). [in Ukrainian].

9. Kobets, R., Pantsyr, S. (ed.) (2008). Publichne lobiiuvannia: navchalnyi posibnyk [Public lobbying: a textbook]. Kyiv: Fond Ievropa KhKh". [in Ukrainian].

10. Konstytutsiia Ukrainy, 1996 [Constitution of Ukraine] (Verkhovna Rada Ukrainy) [(Verkhovna Rada of Ukraine)]. Ofitsiinyi veb-sait Verkhovnoi Rady Ukrainy [The official website of the Verkhovna Rada of Ukraine]. $<$ https://zakon.rada.gov.ua/laws/show/254\%D0\%BA/96-\%D0\%B2\%D1\%80>.(2020, March, 15). [in Ukrainian].

11. Kostjukov, A.N. (2003). Municipalnoe pravo kak otrasl rossijskogo prava [Municipal law as a branch of Russian law]. Moscow. [in Russian].

12. Kuibida, S., Petroie, O.M., Dehtiarova, I.O. (ed.) (2018). Teoriia ta praktyka publichnoho upravlinnia ta administruvannia u XXI storichchi: materialy I Vseukrainskoi naukovo-praktychnoi konferentsii za mizhnarodnoiu uchastiu zdobuvachiv vyshchoi osvity tamolodykh vchenykh (Kyiv, 30 lystopada 2018 r.) [Theory and Practice of Public Administration and Administration in the 21st Century: Proceedings of the I All-Ukrainian Scientific and Practical Conference with International Participation of Higher Education Applicants and Young Scientists (Kyiv, November 30, 2018)]. Kyiv: NADU. [in Ukrainian].

13. Mestnye organy vlasti (1994). Predprinimatel'stvo v Italii [Local Government: Entrepreneurship in Italy]. Moscow. [in Russian].

14. Mistsevi vybory v Ukraini proidut voseny 2020 roku, - holova Verkhovnoi Rady (2020). [The local elections in Ukraine will be held in the fall of 2020, - the Chairman of the Verkhovna Rada]. $<$ https://decentralization.gov.ua/news/11876>. [in Ukrainian].

15. Parshina, E.N. (2009). Obshhestvennyj dogovor kak model vzaimodejstvija institutov i organizacij grazhdanskogo obshhestva s organami vlasti [Social contract as a model of interaction between institutions and civil society organizations with authorities]. Politicheskaja nauka na Juge Rossii: itogi dvadcatiletnego razvitija: sbornik materialov mezhdunarodnoj nauchno-praktich. konf. [Political science in the south of Russia: results of twenty years of development: a collection of international scientific and practical materials. conf.]. Rostov-on-Don: Izd-vo SKAGS, 411-415. [in Russian].

16. Patenok, N.I. (ed.) (2014). Advokatsiia v bibliotetsi: metodyko-informatsiini rekomendatsii [Advocacy in the library: methodological and informational recommendations]. Kyiv. [in Ukrainian].

17. Pidluska, I., Holiuk, O. (2006). Suspilnyi dohovir: vid filosofii davnyny do potreb suchasnosti [The social contract: from the philosophy of antiquity to the needs of today]. Nasha hromada [Our community], 2 (9), 5-8. [in Ukrainian].

18. Pryiniato za osnovu proekt Zakonu "Pro vnesennia zmin do Podatkovoho kodeksu Ukrainy shchodo funktsionuvannia elektronnoho kabinetu ta sproshchennia roboty fizychnykh osib-pidpryiemtsiv" [The Bill "On Amendments to the Tax Code of Ukraine on the Functioning of the Electronic Cabinet and Simplification of Work of Individual Entrepreneurs" was adopted as the basis]. Ofitsiinyi veb-sait Verkhovnoi Rady Ukrainy [The official website of the Verkhovna Rada of Ukraine]. <https://rada.gov.ua/news/Novyny/186699.html>. (2020, March, 15). [in Ukrainian].

19. Radchenko, O.V. (2011). Formy bezposerednoi demokratii terytorialnoi hromady [Forms of direct democracy of the territorial community]. Derzhava ta rehiony. Seriia: Derzhavne upravlinnia [State and regions. Series: Public Administration], 2, 141-145. [in Ukrainian].

20. Russo, Zhan-Zhak, Khoma, O. (trans.) (2001). Pro suspilnu uhodu, abo Pryntsypy politychnoho prava [On social agreement, or Principles of political law]. Kyiv: Port-Royal. [in Ukrainian].

21. Slovnyk ukrainskoi movy: v 11 tomakh (1973). [Dictionary of the Ukrainian language: in 11 volumes]. Kyiv: Nauk. Dumka, 4. [in Ukrainian].

22. Surmin, Yu.P., Mykhnenko, A.M., Krushelnytska, T.P. (2011). Vzaiemodiia orhaniv derzhavnoi vlady ta hromadianskoho suspilstva: navchalnyi posibnyk [Interaction between public authorities and civil society: a textbook]. Kyiv: NADU. [in Ukrainian].

23. Timofeev, N.S. (2005). Mestnoe samoupravlenie v sisteme gosudarstvennyh i obshhestvennyh otnoshenij. Istorija i sovremennost [Local government in the system of state and public relations. History and Modernity]. Moscow. [in Russian].

24. A review of evidence of the bar and its practice for people with limited learning opportunities and high need of support, adults Paper Service 24. SCIE. <http://www.scie.org.uk/>. (2020, March, 15). [in English].

25. Beresford, P., Croft, S. (2004). Users of the service and Practitioners are reunited: a key component of social work reform. British Journal of Social Work, 34 (1), 53-68. [in English].

26. Keck, Margaret E., Sikkink, K. (1998). Activists beyond Borders Advocacy Networks in International Politics. Cornell University Press. [in English]. 
27. Koltun, V. (2018). Complexiti as the immunental properties of local-self-governance phenomenon. Relevant issues of development and modernization of the modern science: the experience of countries of eastern Europe and prospects of Ukraine. Riga, 160-182. DOI: http://dx.doi.org/10.30525/978-9934-571-26-8_9 [in English].

28. Kremers, D. (2014). Transnational Migrant Advocacy From Japan: Tipping the Scales in the Policy-making Process. Pacific Affairs, 87 (4), 733. doi:10.5509/2014874715. [in English].

29. Manthorpe, J., Rapaport, J., Hussein, S., Moriarty, J., Collins, J. (2006). Advocacy and People with Disabilities: Localthe power of the sphere of its activity, degree and efficiency. London: Kings College London. [in English].

30. Obar, J.A., Zube, P., Lampe, C. (2012). Advocacy 2.0: An analysis of how advocacy groups in the United States perceive and use social media as tools for facilitating civic engagement and collective action. Journal of Information Policy, 2, 1-25. doi:10.2139/ssrn.1956352. SSRN 1956352. [in English].

31. Planet Advocacy Magazine (2020). Action For Advocacy.

$<\mathrm{http} / /$ www.actionforadvocacy.org.uk/articleServlet_action=list\&articletype=22>.(2020, March, 15). [in English].

32. Warren, M.E., Pearse, H. (eds.) (2008). Designing Dēliberative Democracy: The British Columbia Citizens' Assembly. New York: Cambridge University Press. [in English]. 